\title{
BMSAP
}

Bulletins et mémoires de la Société d'Anthropologie de Paris

BMSAP

34 (1) | 2022

Entre vivants et morts : regards croisés sur une frontière relative et fluctuante

\section{Considerations on the mechanisms of integration of the dead in the early sedentary societies of the Near East (Natufian, 15-11.6 ka cal BP)}

Réflexions sur les mécanismes d'intégration des morts aux premières sociétés sédentaires du Proche-Orient (Natoufien, 15-11,6 ka cal BP)

Fanny Bocquentin and Camille Noûs

\section{OpenEdition}

Journals

Electronic version

URL: https://journals.openedition.org/bmsap/9548

DOI: $10.4000 /$ bmsap.9548

ISSN: $1777-5469$

Publisher

Société d'Anthropologie de Paris

Electronic reference

Fanny Bocquentin and Camille Noûs, "Considerations on the mechanisms of integration of the dead in the early sedentary societies of the Near East (Natufian, 15-11.6 ka cal BP)", Bulletins et mémoires de la Société d'Anthropologie de Paris [Online], 34 (1) | 2022, Online since 19 February 2022, connection on 12 February 2023. URL: http://journals.openedition.org/bmsap/9548 ; DOI: https://doi.org/10.4000/ bmsap.9548 


\title{
Considerations on the mechanisms of integration of the dead in the early sedentary societies of the Near East (Natufian, 15-11.6 ka cal BP)
}

\author{
Réflexions sur les mécanismes d'intégration des morts aux premières sociétés \\ sédentaires du Proche-Orient (Natoufien, 15-11,6 ka cal BP)
}

Fanny Bocquentin ${ }^{1 *}$, Camille Noûs ${ }^{2}$

1. CNRS, UMR 8068 TEMPS, MSH Mondes, Nanterre, France

2. Laboratoire Cogitamus, France [https://www.cogitamus.fr/indexen.html]

* fanny.bocquentin@cnrs.fr

Reçu : 24 juillet 2021 ; accepté : 24 novembre 2021 Bulletins et Mémoires de la Société d'Anthropologie de Paris

Cette note fait suite à une communication présentée lors des $1846^{\text {es }}$ journées de la Société d'Anthropologie de Paris dans le cadre de la session "Entre vivants et morts : regards croisés sur une frontière relative et fluctuante"

\begin{abstract}
With the beginning of sedentary life in the Near East, the practice of burying the dead, which was exceptional throughout the Palaeolithic period, became widespread. From then on, an enduring relationship became established between the living and the dead coexisting in the same settlement, and it seems that the boundary that separated them began to blur. As many burials were excavated long ago, the spatial and stratigraphic evidence and the treatment of corpses are often imprecise. However, there are still indications that a dynamic of interdependence between the living and the dead became more marked over time. We show that, well beyond their passive occupation of the territory of which they are presumed to have been the guardians, the dead took on a decisive role in the foundation and the subsequent restructuring of settlements. The location of the graves and the succession of activities and constructions are evidence of deliberate planning of the dwelling space, in which the role of each actor became sustained over time. The alternation of individual and collective treatments of the deceased seems to correspond to changes in the occupation of each settlement. It can then be seen that if the relationship between graves and dwellings is loosened, the funerary time span lengthens and the boundary between the living and the dead becomes permeable.
\end{abstract}

Keywords - Natufian, sedentism, burials, spatial organization, funerary time span

Résumé - Avec le début de la sédentarité au Proche-Orient, le phénomène sépulcral, exceptionnel pendant toute la durée du Paléolithique, devient pratique courante. Dès lors, rassemblés dans l'habitat, vivants et morts entretiennent une relation au long cours et la frontière qui les sépare semble se brouiller. Beaucoup de sépultures ayant fait l'objet de fouilles anciennes, la lecture des liaisons spatiales et stratigraphiques et celle du traitement du corps défunt s'en trouvent aujourd'hui imprécises. Pourtant des indices subsistent d'une dynamique d'interdépendance qui s'accroît au fil du temps. On montrera, que bien au-delà d'une occupation du territoire dont ils seraient les gardiens, les morts prennent une place qui est déterminante dans la fondation puis la restructuration du hameau. L'emplacement des tombes, la succession des activités et des constructions témoignent d'une planification de l'espace où s'inscrit durablement le rôle de chacun. L'alternance d'un traitement individualisé et collectif des défunts semble correspondre à des modifications d'occupation des hameaux. On constate alors que si le lien entre sépultures et habitat se relâche, le temps funéraire s'allonge et la frontière qui sépare vivants et morts devient perméable.

Mots clés - Natoufien, sédentarisation, inhumations, organisation spatiale, temporalité funéraire

\section{Introduction}

The aim of this article is to explore how the relationship between the living and the dead was reshaped in a context of sedentism. The establishment of a permanent settlement created an enduring boundary between the dwelling space and the rest of the world, which thus restructured the dynamics - economic, social and symbolic of the territory (e.g. Gagnol, 2011). The place of the dead in this new spatial construction can be investigated through the location of their graves, the treatment of corpses and how their memory was preserved. 
We will deal here with the particular case of the primosedentary communities of the Near East. At the end of the Pleistocene, the return of warmer climatic conditions (Bǿlling-Allerǿd) coincided with the foundation of the first hamlets. From the $13^{\text {th }}$ millennium cal BC, small communities of hunter-gatherers living in a Mediterranean-type ecosystem settled in the same place over several generations. They were named Natufians after the eponymous valley, Wadi-en-Natuf(Palestine), where the first site was discovered in 1928 by Dorothy Garrod (e.g. Bar-Yosef and Valla, 2013). In contrast, the preceding period, named the Geometric Kebarian, was characterised by high mobility in a context of major climatic instability (e.g. Enzel and Bar-Yosef, 2017). However, the foundation, which was sudden on an archaeological scale, of these first Natufian hamlets with massive architectural features seems to be evidence of a mature project facilitated by constructed social spaces and a knowledge of the surrounding resources acquired long before, during the recurrent use of aggregation sites since the beginning of the Epipalaeolithic (e.g. Byrd, 2005; Ramsey et al., 2016; Valla, 2018; Yeshurun and Bar-Oz, 2018).

Pre-Natufian burials are rare, being sparsely scattered over the millennia, yet they provide evidence of a funerary pattern that had existed since the Middle Palaeolithic and in which the practice of burying corpses remained extremely marginal (e.g. Hovers and Belfer-Cohen, 2013; Vandermeersh and Bar-Yosef, 2019). The increase in the number of graves during the Natufian period reflects a shift in practices towards increasingly frequent corpse interment, which finally became the norm in the Neolithic period. Moreover, by burying their dead within their hamlets, the Natufians inaugurated a long period of close relationships between the living and the dead that continued and intensified throughout the Pre-Pottery Neolithic, declining thereafter from the beginning of the $6^{\text {th }}$ millennium cal BC. Nonetheless, just as sedentary life did not evolve in a linear mode, neither did the treatment of the dead, which bears witness to a fluctuating relationship between the living and the dead according to the ever-shifting spatial and temporal boundaries between them. Our aim here is to identify evidence of this relationship through different aspects of funerary treatments and to put forward possible interpretations.

\section{Natufian landmarks}

Long considered as the cradle of the Natufian culture, the southern Levant has yielded major reference sites, but early occupations are now equally known in the northern Levant (see the recent distribution map in Bocquentin, 2020 and figure 1). The arrangement of the dwellings in relation to each other, in a linear or honeycomb pattern, shows careful organisation of the hamlet (e.g. Bar-Yosef and Belfer-Cohen, 1999; Terradas et al., 2013). These houses are circular, semi-circular or oval. The oldest are the largest and their robustness is evidence of a spectacular development of architectural techniques. Their rows of stone stand on the wall of a pit dug before their construction.

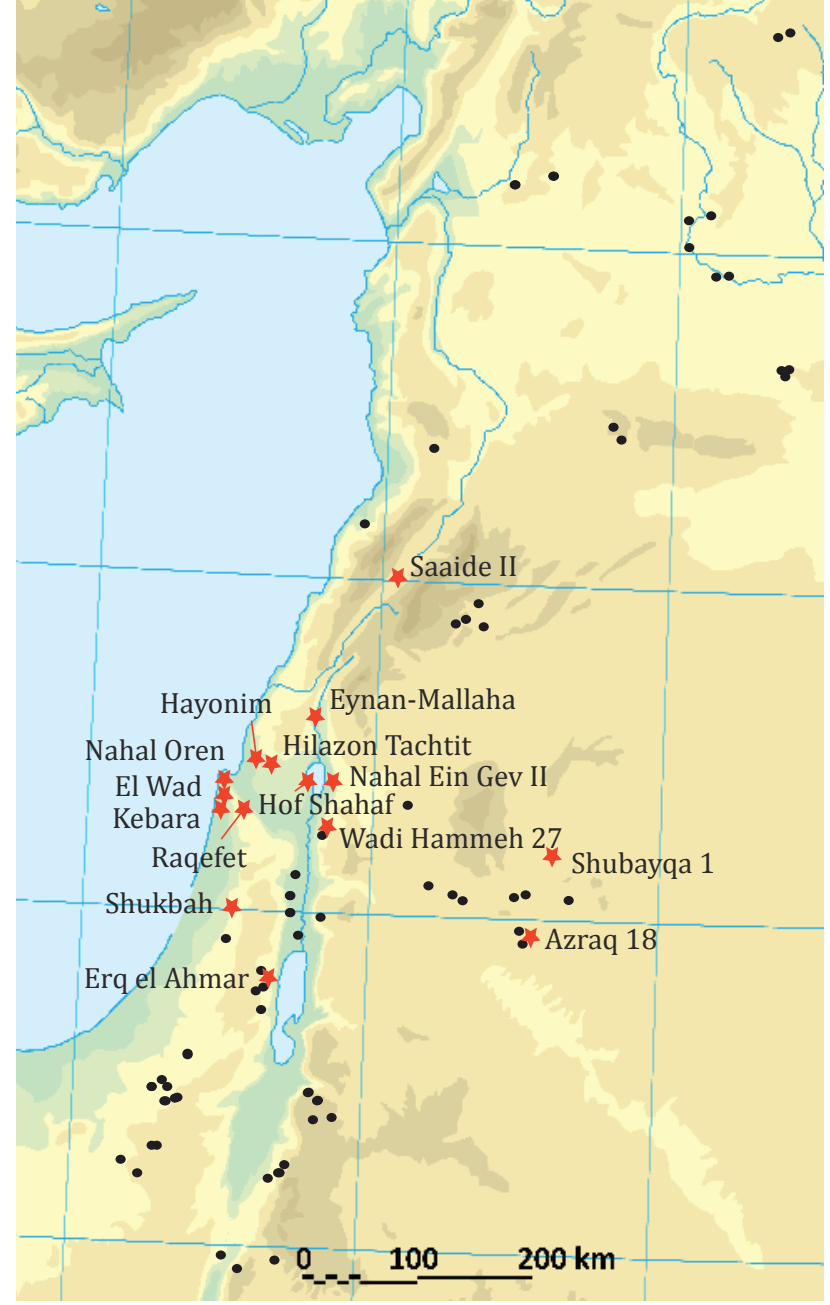

Figure 1. Natufian sites with grave(s) (red stars and names) and distribution of other major sites (black dots) (Ground Map: (C) Martin Sauvage) / Sites natoufiens avec sépulture(S) (étoiles rouges et noms) et distribution des autres sites majeurs (points noirs) (Fond de carte : (C) Martin Sauvage)

Although no walls partitioning the internal space of the dwelling have been preserved, the few spatial analyses carried out show that the different craft activities, the areas used for storing or discarding and the location of the hearths are strictly ordered according to an arrangement that is sometimes maintained on several superimposed levels (Valla, 1988; Samuelian, 2019). The structures were regularly restored or rebuilt one on top of the other.

The Natufian period is divided into three phases: Early (13-11.6 ka cal BC), Late (11.6-10.6 ka cal BC) and Final (10.6-9.6 ka cal BC). Although clearly identified at certain sites (e.g. Eynan-Mallaha), recognition of this last cultural phase, immediately preceding the Pre-Pottery Neolithic, suffers from a lack of detailed stratification and dating (hampered by the radiocarbon plateau) and, undoubtedly, from the still poorly diagnosed diversity of archaeological expression. 
From the beginning of the Early Natufian, certain huntergatherer communities acquired a fully sedentary lifestyle, as argued by a number of scholars based on evidence now assembled at several sites (material accumulation, thickness of stratigraphy, occupation during the four seasons, multiple activities, integrity of the chaînes opératoires and high rates of commensal species) (e.g. Weissbrod et al., 2017; Valla, 2018). This does not exclude the presence of numerous ephemeral sites, particularly in the least favourable ecosystems. Moreover, strontium isotope studies suggest continuing significant mobility of individuals during the course of their life within the Natufian territory (e.g. Santana et al., 2021). In the permanent hamlets, many burials are located within the domestic space. The Late Natufian marks a shift that seems to precede, at least in the Mediterranean context, the cold and arid climatic deterioration of the Late Dryas (11-9.5 ka cal BC). Several sites in the southern Levant were abandoned, evoking a return to a nomadic life, but the changes observed from one site to another are not identical and could be the materialisation of different adaptation strategies depending on communities and on the ecological niches they occupied (e.g. Henry, 2013). Some caves of this time are considered to be exclusively funerary and ceremonial (Raqefet, Hilazon Tachtit). The end of the Natufian is marked by a return to stable occupation, with burials once again closely associated with hamlets (Mallaha, Nahal Ein Gev).

Over the generations, these different hunter-gatherer communities maintained their specific features, but local exchanges intensified through food and raw material procurement and the circulation of objects, ideas and people, favouring the establishment of a strong Natufian identity. Funerary norms and the manufacture of ornaments and utilitarian objects decorated with recurring figurative or geometric motifs both suggest a community of values and beliefs beyond the similarities in lifestyle and technical practices (e.g. Bocquentin et al., 2010; Edwards et al., 2019 and figure 2).

\section{A process of selective aggregation}

The integration of the dead initially took place through a process of aggregation. The dead were included in the domestic space alongside the living. Graves are omnipresent in the main hamlets. Excavations in the 1930s considered that the Natufian sites were mainly cemeteries of mobile groups (Garrod and Bate, 1937), until the first houses were finally identified and the sedentary lifestyle of these hunter-gatherers was brought to light from the end of the 1950s (Perrot, 1960; 1966). Thus, the dead, who were exceptionally buried in ephemeral Palaeolithic camps, were henceforth regularly buried near the living. The term cemetery, still in use today, conceals a complex reality where the impression of a dense aggregation of houses and burials is in the end only a palimpsest resulting from a variety of interactions and stratigraphic relationships between the living and the dead over a long period of time. There is, generally speaking, no separate space in the hamlet dedicated to the dead over several generations, but a single and continuous space where the living and the dead, all sedentary, would rub shoulders and cross paths in a discontinuous temporality.

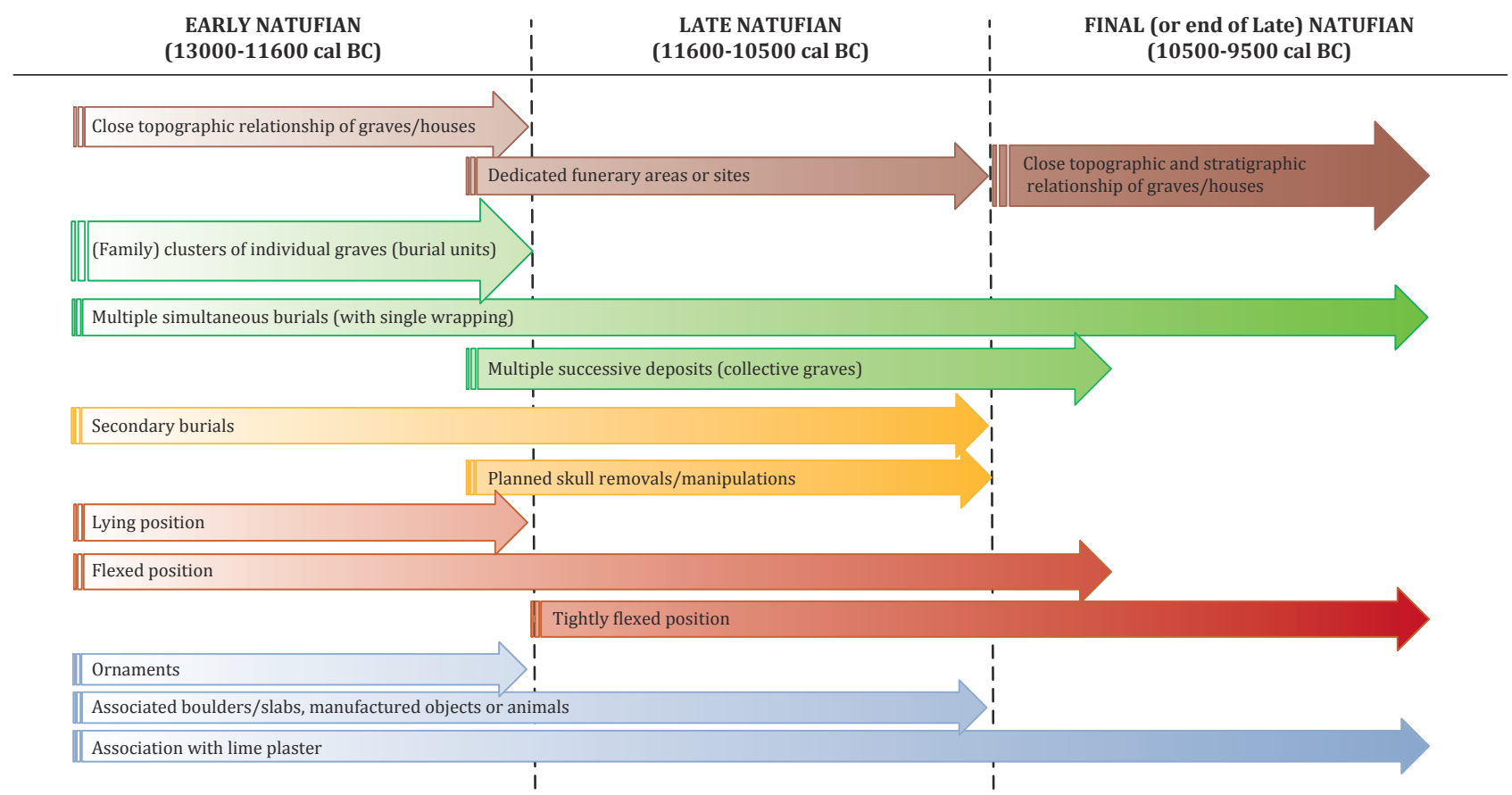

Figure 2. Major evolutionary trends in funerary treatment over time, according to the three chronological phases defined for the Natufian Culture / Principales tendances évolutives du traitement funéraire selon les trois phases chronologiques définies pour la culture natoufienne 
However, these sedentary dead were not all of the dead. The Natufian assemblage now comprises approximately 430 individuals found in clear burial contexts, that is to say excluding isolated remains. The majority of these graves were found in the Carmel and Galilee areas. Although exceptional in terms of Pleistocene assemblages, the Natufians are represented, on average, by one individual per decade, which corresponds to an extremely small sample of the past Natufian population (Bocquentin, 2003). If it were random, our available sample would follow the expected mortality profile of a pre-vaccination population and include a nearequivalent number of females and males (e.g. Ledermann, 1969; Sellier, 1996; Hoppa, 2002). But this is far from being the case. On average, the male sample is double the size of the female sample (figure 3). Secondly, even considering the highest expected life expectancy at birth for pre-Jenner demography, we are missing at least $80 \%$ of infants and $50 \%$ of deaths before the age of 5 in relation to the number of adults (who are themselves under-represented; figure 4a). The variable selection rates according to phases or sites (figure 4b) show that this is not a simple matter of taphonomy but of funerary eligibility. For instance, at Shubayqa 1 some buildings, if not the entire site, are dedicated to the youngest, which is in total contrast with the usual pattern observed (Richter et al., 2019). Hayonim cave was clearly dedicated to adolescents and young males during the Early Natufian (Belfer-Cohen et al., 1991; Bocquentin, 2003). Thus, criteria linked to age-at-death and sex play a role in eligibility for burial, but they are not final because, for example, some women and babies have also been found in the hamlet. Other structural criteria may be suggested by known burial clusters. For instance, potential emotional ties
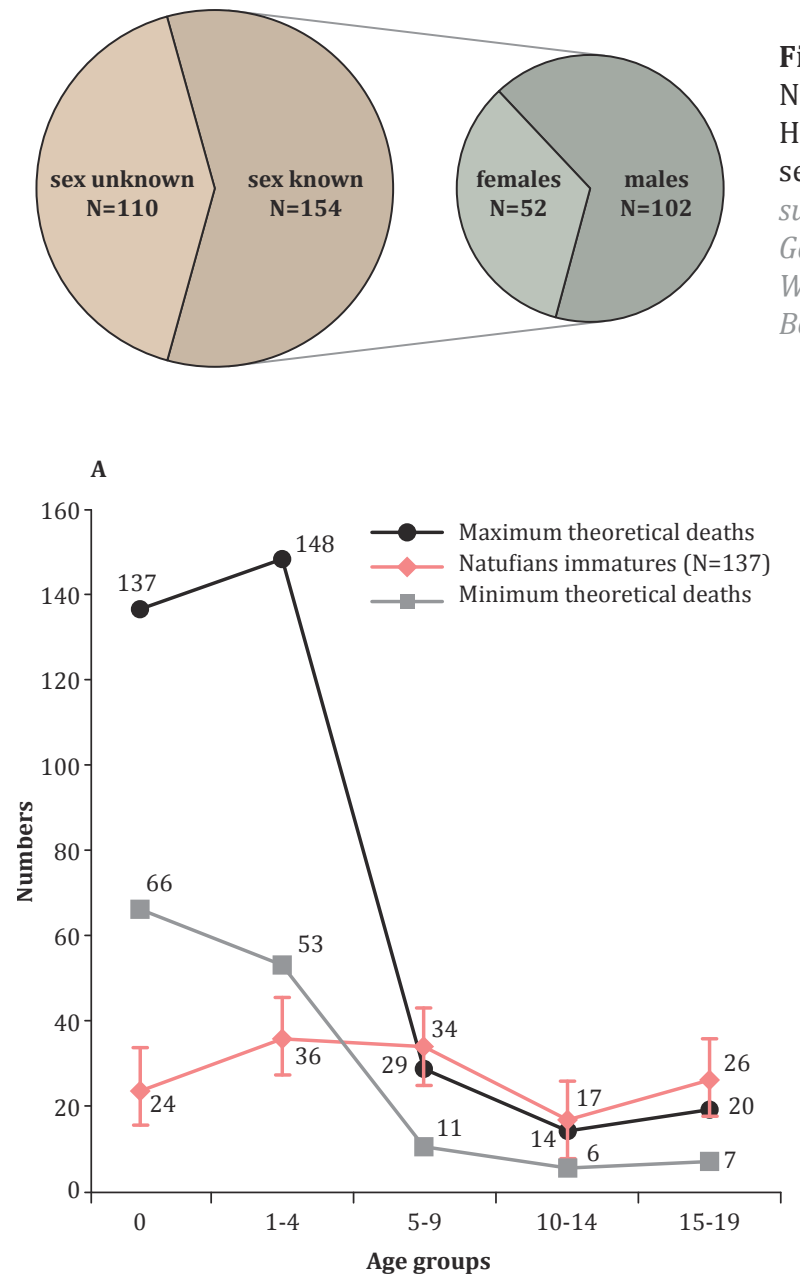

Figure 3. Sex distribution based on adult skeletons from Shukbah, Nahal Oren, El Wad (Garrod's excavation), Raqefet, Eynan-Mallaha, Hayonim Cave, Kebara, Azraq 18, Wadi Hammeh 27. For methods of sex determination see Bocquentin, 2007 / Distribution par sexe basée sur les squelettes adultes de Shukbah, Nahal Oren, El Wad (fouille de Garrod), Raqefet, Eynan-Mallaha, Hayonim Cave, Kebara, Azraq 18, Wadi Hammeh 27. Pour les méthodes de détermination du sexe, voir Bocquentin, 2007

Figure 4. A) Distribution of Natufian immatures (with 95\% confidence intervals) in the main assemblages compared to the expected distribution according to Pre-Jenner mortality profiles for a life expectancy at birth ranging from 25 to 40 years. B) Distribution by age class of the main Natufian assemblages compared to the distribution for a life expectancy at birth of 30 years (reference demographic tables after Ledermann, 1969. For methods of age determination see Bocquentin, 2007) / A) Distribution des immatures du Natoufien (avec intervalles de confiance à 95\%) des principaux assemblages comparée à la distribution attendue selon les profils de mortalité pré-jénériens pour une espérance de vie à la naissance comprise entre 25 et 40 ans. B) Distribution par classe d'âge des principaux assemblages natoufiens comparée à la distribution pour une espérance de vie à la naissance de 30 ans (tableaux démographiques de référence d'après Ledermann, 1969. Pour les méthodes de détermination de l'âge, voir Bocquentin, 2007) 
may have connected the man and woman entwined in El Wad cave (figure 5a), or the two children found buried together at Wadi Hammeh 27 (Edwards et al., 2018). At Eynan-Mallaha, the adults of locus 240 show heavily worn teeth with a unique wear pattern. It is likely that they were engaged in a specific, yet to be defined, craft activity involving intensive use of teeth, which united them in life and in death (figure 5b). Biological kinship is also a criterion for selecting and organising the dead in a space, as shown previously based on discrete traits found in high concentrations in some graves attributed to the Early Natufian (Smith, 1973; Bocquentin, 2003). For the Late and Final Natufian, such family clusters have not yet been identified and may not have existed.
Thus, the dead were settled in the hamlet, aggregated with the living and selected on various criteria where biological identity, social role, or perhaps emotional or dependency ties might have come into consideration alongside other criteria that remain unidentified. The non-elected dead were excluded from the domestic space and, in all likelihood, were not buried but received a funeral treatment that has left no trace, like most of their Palaeolithic predecessors. The presence of isolated remains, outside a clear burial context, leaves the hypothesis open of the existence of an in-between treatment in which only a few bones of the excluded dead could have been brought back to the dwellings at some point.
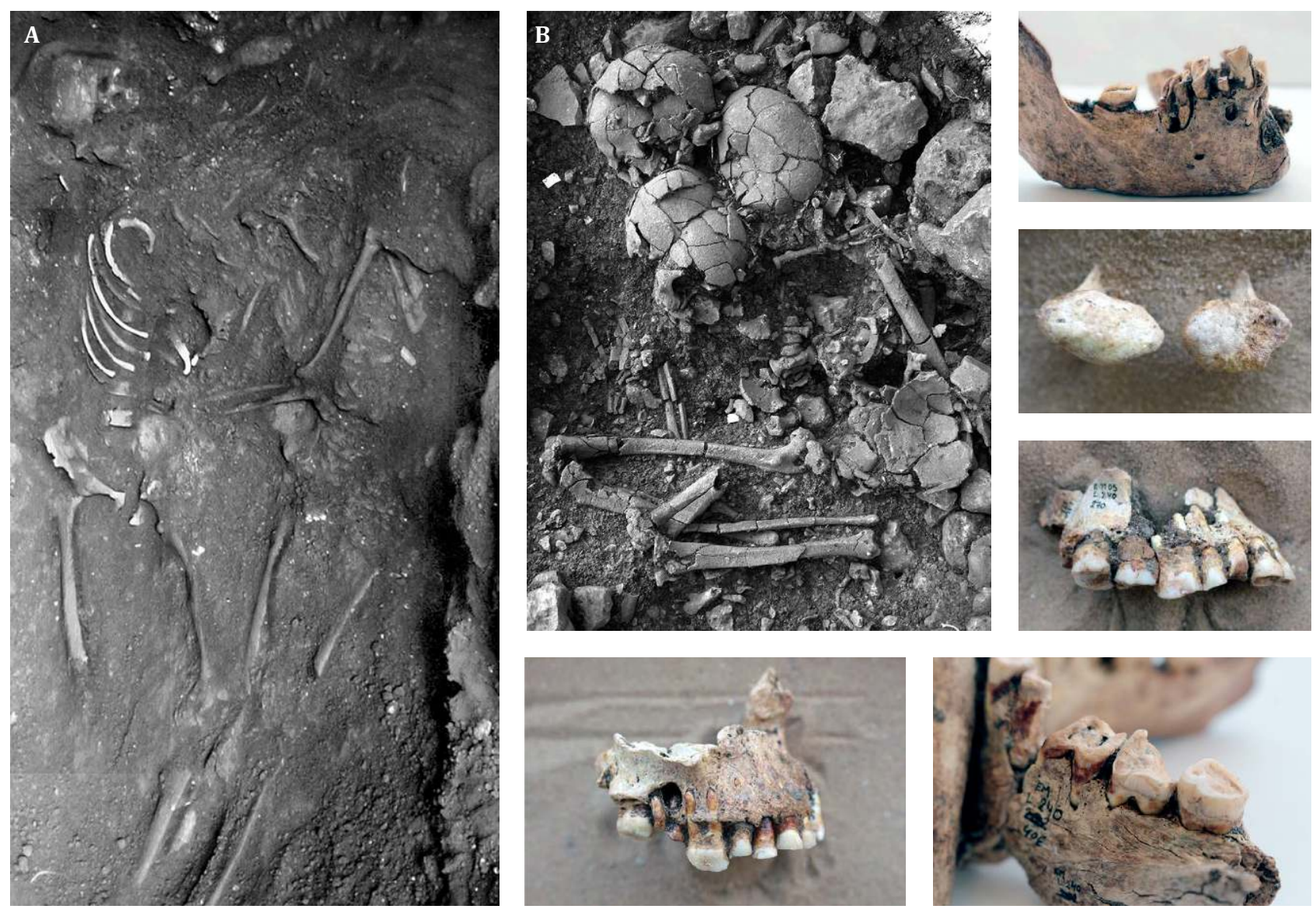

Figure 5. A) Simultaneous double burial H2-H3 within the H1-H10 cluster of graves at El Wad Cave. These are 2 adults, male and female, facing each other with their forearms entwined (ㄷ Archives from the Fonds DAE Garrod, Musée d'Archéologie nationale, Saint-Germain-en-Laye). B) Collective grave from Mallaha (Locus 240). Of the 5 adults present, 4 show use of the teeth as tools for a repetitive activity (yet to be precisely determined). The teeth are worn in unusual ways, the enamel is frequently broken and the articular surfaces of the mandibular condyles also show intense chewing activity associated with significant deposits of tartar (ongoing analyses). These individuals clustered together in death may well have shared a common socioeconomic role during life (photographs of the locus (C) F. Valla; photographs of the teeth (C) F. Bocquentin) / A) Sépulture double simultanée H2-H3 faisant partie de l'ensemble sépulcral H1-H1O de la grotte d'El Wad. Il s'agit de 2 adultes, homme et femme, se faisant face, enlacés par leurs avant-bras (@ Archives du Fonds DAE Garrod, Musée d'Archéologie nationale, Saint-Germain-en-Laye). B) Sépulture collective de Mallaha (locus 240). Sur les 5 adultes présents, 4 montrent une utilisation des dents comme outils pour une activité répétitive (qui reste à déterminer précisément). Les dents sont usées de manière inhabituelle, l'émail est fréquemment cassé et les surfaces articulaires des condyles mandibulaires montrent également une activité masticatoire intense associée à d'importants dépôts de tartre (analyses en cours). Ces individus regroupés lors du décès partageaient probablement un rôle socio-économique commun durant leur vie (photographies du locus (c) F. Valla ; photographies des dents (C) F. Bocquentin) 


\section{Co-construction of the living space}

Topographically, a large majority of Natufian graves are located in houses. This is especially the case for the Early and Final Natufian phases; we will deal with the particular case of the Late Natufian later. The question of whether these burials were contemporary, post-dating or pre-dating occupation of the houses, is crucial, as it is this question of temporality that can allow us to place the boundary of interactions between the Natufians and their dead. However, the Natufian sites are an accumulation of successive deep diggings: houses, hearths, post-holes, various pits that are superimposed, juxtaposed or intersect in sediments, which, in the vast majority of cases, whether in caves or in the open areas, do not allow the limits of the pits to be legible during field work (figure 6). Thus, only a very meticulous excavation of the graves and the floors can possibly reconstruct their exact stratigraphic relationships. This information is available for a handful of graves among the hundreds discovered since 1928. In the cases where the stratigraphic sequence could be reconstructed, it appears that graves and occupation levels in fact alternate (e.g. Valla and Bocquentin, 2008). With a few exceptions, of perinatals possibly buried in occupied houses, graves were often dug into temporarily abandoned houses while floors were installed on top of previous burial grounds. Which came first: the grave or the house? In several sites, graves could be the first evidence of occupation, as suggested long ago at Hayonim Cave (Bar-Yosef and Goren, 1973) and more recently at Mallaha, Wadi Hammeh 27, Nahal Ein Gev 2 or Shubayqa 1 (e.g. Valla and Bocquentin, 2008; Grosman et al., 2016; Edwards et al., 2018; Richter et al., 2019). In fact, the issue has not been definitively answered because it must be proven with certainty that the graves were not dug from a level that was subsequently eroded or re-dug, or that the burial pits did not completely destroy an occupation floor that predated their existence. Unless the excavation is sufficiently fine-tuned and focused on these questions, the chances of finding answers are slim. However, it has been shown at Mallaha that the oldest

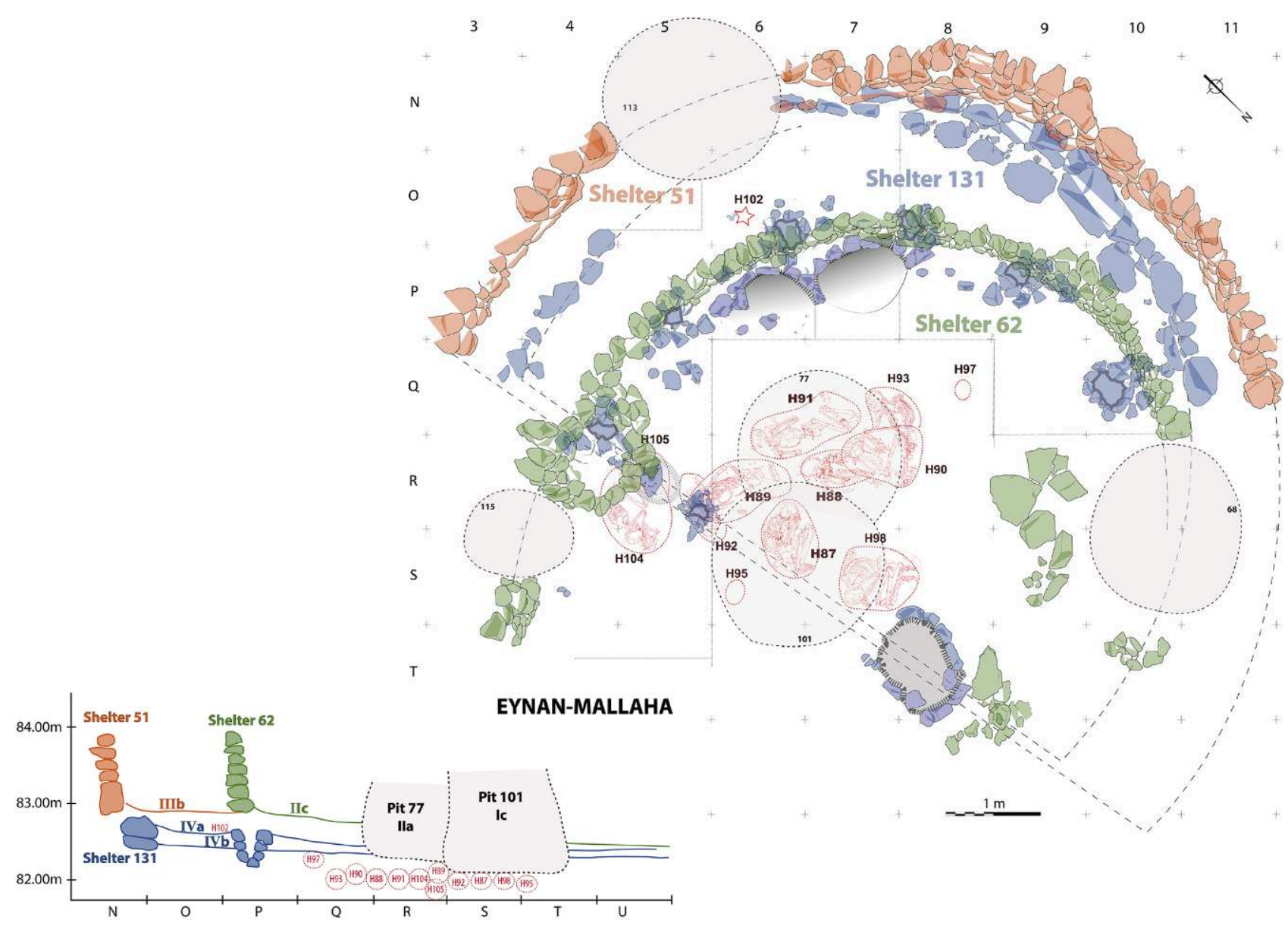

Figure 6. Succession of occupations over time in one of the sectors of the Mallaha site. Shelter 131 (blue) is built on a group of graves (red). Shelter 51 (brown) overlaid them before being cut by shelter 62 (green), itself partly destroyed by deep pits (grey), some of which cut into the earlier graves (after Davin, 2019) / Succession des occupations au cours du temps dans un des secteurs du site de Mallaha. L'abri 131 (bleu) est construit sur un ensemble de tombes (rouge). L'abri 51 (marron) les recouvre avant d'être lui-même recoupé par l'abri 62 (vert), lui-même partiellement détruit par des fosses profondes (gris) dont certaines recoupent les tombes antérieures (d'après Davin, 2019) 
graves, if not necessarily the first evidence of occupation of the site, at least predate the houses (shelters 1 and 131) in which they were found (Perrot and Ladiray, 1988; Valla and Bocquentin, 2008; Valla, 2019). The structures were built on top of the graves, which a posteriori ended up beneath the central part of the living floor or near the entrance threshold and oriented in the same cardinal directions. Therefore, the establishment of the house was not random but fully integrated the material existence and specificity of the underlying graves (figure 6).

Over time, houses and graves alternate at an increasingly rapid pace. During the Final Natufian, the rotation between the dead and the living was sometimes shorter than the time of corpse decay (Bocquentin et al., 2013), making potential coincidence or ad hoc behaviour unlikely. Taphonomical analyses have allowed the reconstruction of microchronological sequences at Eynan-Mallaha, enabling us to follow the pattern of alternation step by step. One example is a particularly eloquent case where a hearth (Locus 234), a skeleton (H156) and a floor (Locus 203a) are directly superimposed one over the other, providing evidence of a change in spatial function where the burial acted as a trigger. The place was first used for open-air pyrotechnical activities and was converted into a shelter as soon as the funerary deposit took place. Only after the corpse had decayed would the shelter have been inhabited by the living (see Bocquentin, 2022 for the taphonomical arguments). Thus a liminal period is observed in this specific case during which the living space was placed in abeyance while waiting for the corpse to decay and maybe for the deceased to cross over to the world of the dead.

The temporal boundary between the living and the dead is thin, but the physical boundary is sometimes even thinner, to the point where the two worlds are no longer distinguishable. This permeability is materialised, for instance, by the numerous human bones scattered across the dwelling space. It is true that the semi-buried buildings favoured the chances of accidental bone exhumations, to which Natufians did not always seem to pay particular attention. But there are eloquent exceptions, such as those lying on occupation floors, including a cranial vault of which the volume is preserved (figure 7). Their presence has been considered to be symbolically significant (Valla, 1988; Webb and Edwards, 2002) but no systematic study of quantitative, qualitative and spatial data has been done so far. Beyond their passive presence, the contribution of scattered human bones to the construction of a large outdoor fireplace at Mallaha, discovered crushed between two stone courses of the inner wall (Valla et al., 2004), raises the question of the use of the dead as a building material (figure 8). This echoes other observations where corpses are partly embedded in buildings, which was first noted in a Final Natufian

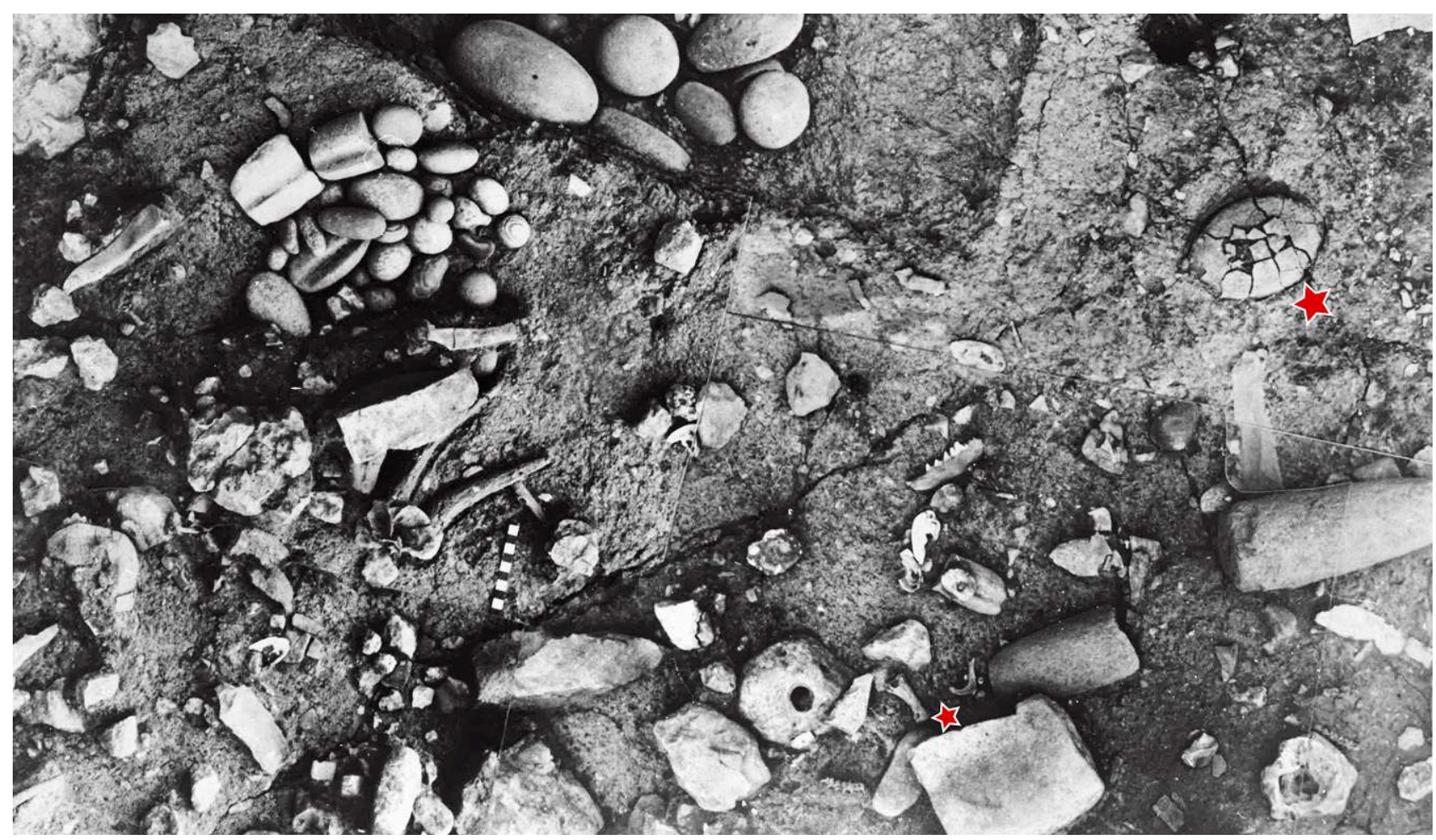

Figure 7. Photograph showing part of the IVa occupation floor and underlying IVb floor of shelter 131, excavated in 1975 by F. Valla and his team. Note the strict ordering of the items. The two stars indicate human remains: a cranial vault fragment (H102: see figure 4) and a Metacarpal Rey 1 (C) Archives from the Fonds Perrot, JP583, Maison des Sciences de l’Homme, Nanterre) / Photographie partielle des sols d'occupation IVa et sous-jacents IVb de l'abri 131 fouillés en 1975 par F. Valla et son équipe. Notez la disposition ordonnée des vestiges. Les deux étoiles mettent en évidence des restes humains : un fragment de voûte crânienne (H102 : voir figure 4) et un métacarpien I (@ Archives du Fonds Perrot, JP583, Maison des Sciences de l'Homme, Nanterre) 


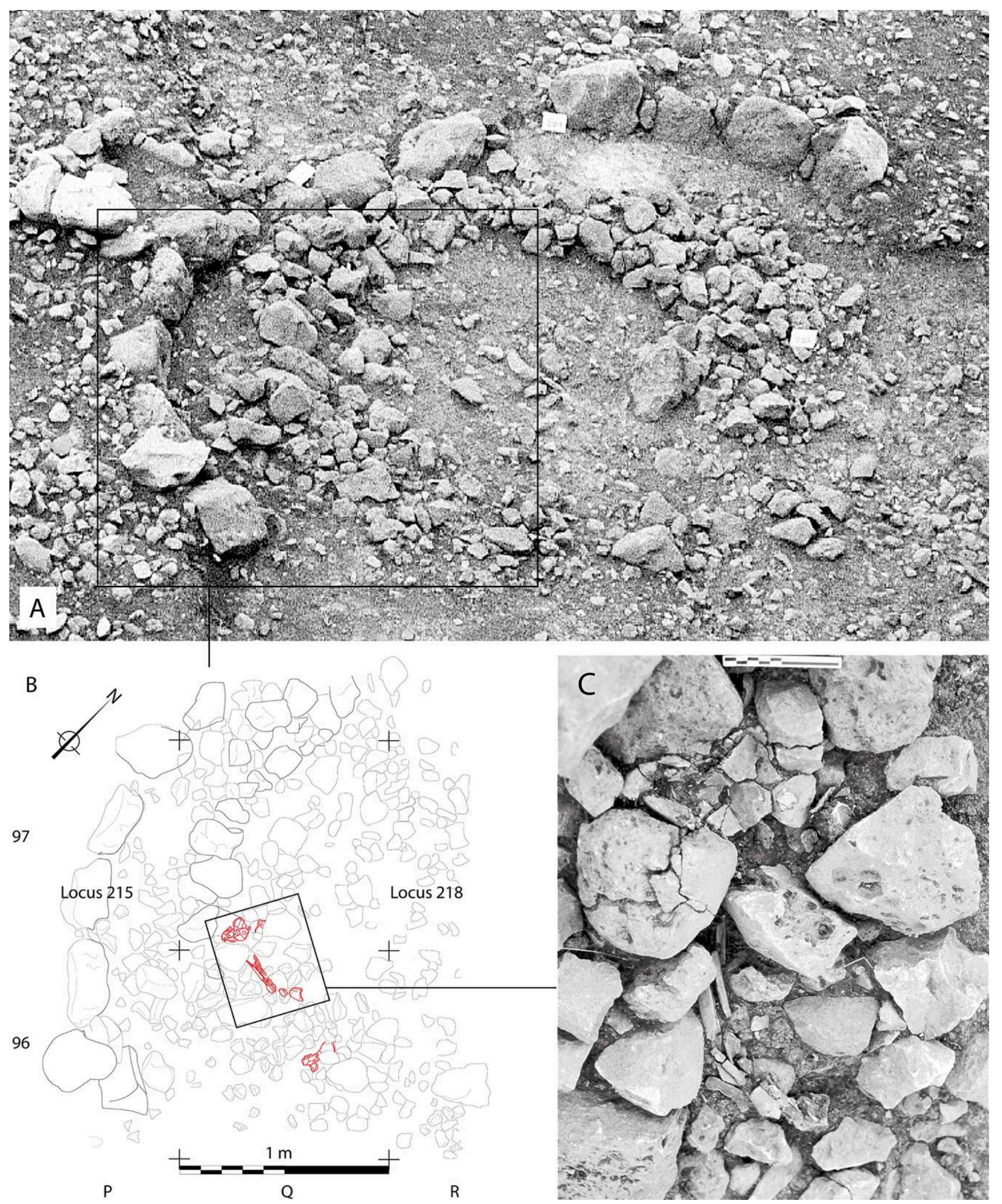

Figure 8. Embedded structures 215 (wall) and 228 (fireplace) at Mallaha. Human remains were found crushed between two courses of stones. In square Q97, a mandible, an occipital fragment, a zygomatic fragment and a calcaneus were found. In square Q96, a distal half of a right tibia and an entire right coxal bone were present (after Valla et al., 2004) / Structures emboîtées 215 (mur) et 228 (cheminée) à Mallaha. Les restes humains ont été retrouvés écrasés entre deux assises de pierres. Dans le carré Q97, une mandibule, un fragment occipital, un fragment zygomatique et un calcanéum ont été trouvés. Dans le carré Q96, une moitié distale d'un tibia droit et un os coxal droit entier étaient présents (d'après Valla et al. 2004) 


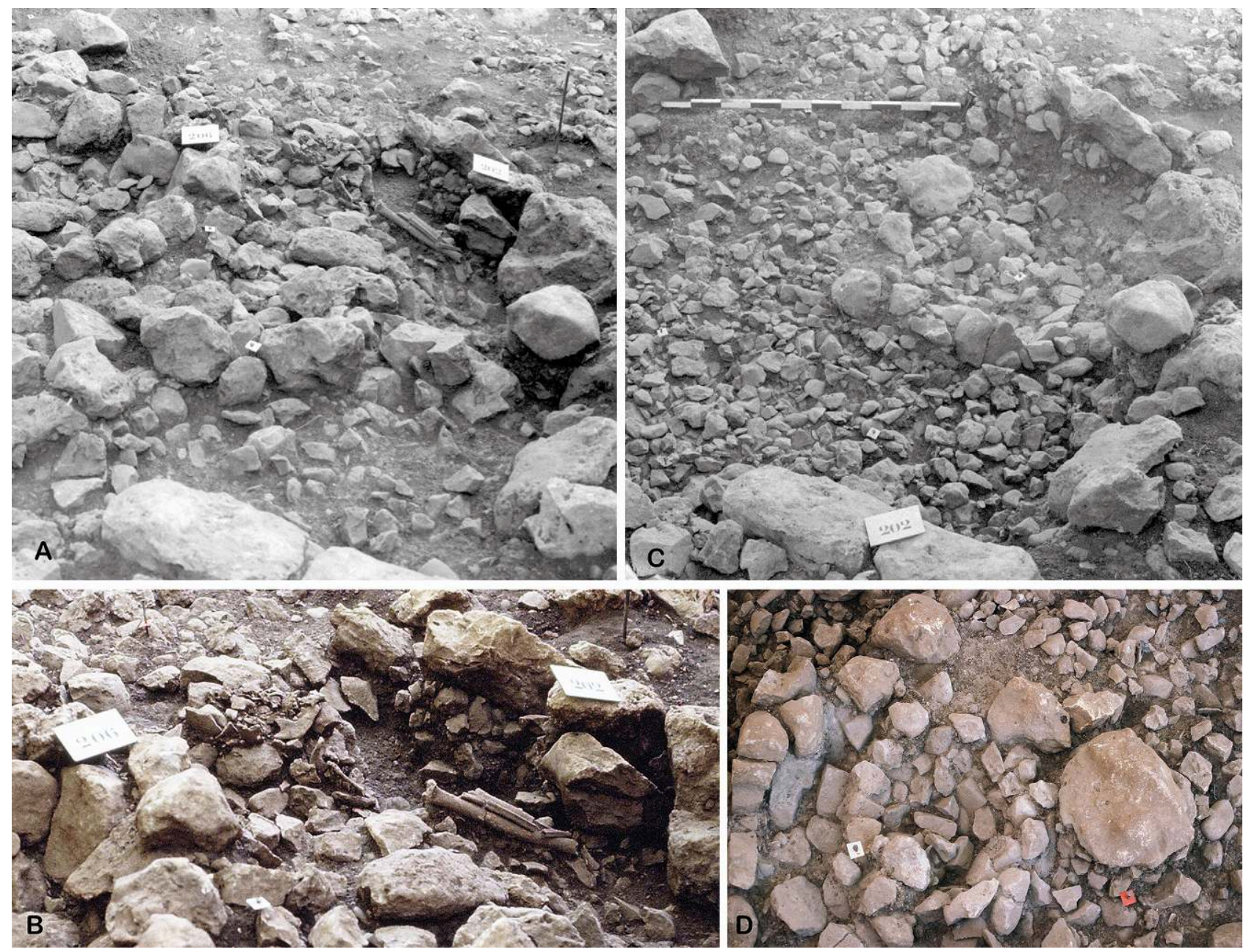

Figure 9. Embedded loci 202 (surrounding wall) and 206 (large basin) (function unknown) at Mallaha. A) Skeleton H157 lying on the external wall of basin 206. B) Close-up view. C) Same point of view after removing H157 and the basin: hearth 235 is exposed. This structure was no longer visible at the time of the funerary deposit but the skeleton is placed right above it. D) Close-up view of locus 235 (C F. Valla) / Structures emboîtées 202 (mur périphérique) et 206 (grand bassin) (fonction inconnue) à Mallaha. A) Squelette H157 reposant sur le mur extérieur du bassin 206. B) Vue rapprochée. C) Même point de vue après avoir démonté $H 157$ et le bassin : le foyer 235 est apparent. Cette structure n'était plus visible au moment du dépôt funéraire mais le squelette est placé juste au-dessus. D) Vue rapprochée du locus 235 (C F. Valla)

structure (Valla et al., 2001). A skeleton (H157) was found lying on the external wall of a huge stone basin (Locus 206) and its feet, still articulated, were found directly under the stones of a curvilinear wall surrounding the basin (Locus 202). The removal of the basin later revealed that a hearth (Locus 235) was located right under the overlying grave (figure 9). This shows that, on the one hand, the construction of the peripheral wall was contemporary with the burial and that the corpse was not placed just anywhere but above a meaningful structure which, however, was no longer visible at the time of the funeral. Comparable cases of articulated feet deeply embedded in walls are highlighted in the notebooks of Jean Perrot, but he did not mention these in the final publication (Perrot and Ladiray, 1988; figure 10). It must be said that such stratigraphic complexity is puzzling. The grave placed directly on the structure rendered it non-functional by sealing it off, and is itself locked beneath a new construction. The dead thus became one with the hamlet. Another case of direct fusion of corpse and structure can be discerned from a photograph taken at Nahal Oren: the fully articulated skeleton is lying partly on a slab of a huge fireplace and partly on a second adjacent stone structure (Bocquentin 2003, fig. 78). What is common to all these cases is that the dead are not buried in a pit: they are placed on the structure, in almost direct contact with the stones. Almost, because the lateral constraints observed on the skeletons (e.g. verticalization of the scapulas) and the strong anatomical coherence with joints still articulated testify to the use of funerary bags or containers surrounding the corpse. A mound of earth was necessarily piled onto the structure and the corpse, otherwise no permanent preservation would have been possible. The absence of burial pits must be emphasised: the graves sealed off the past without destroying it and linked the world of the living with that of the dead as closely as possible. 


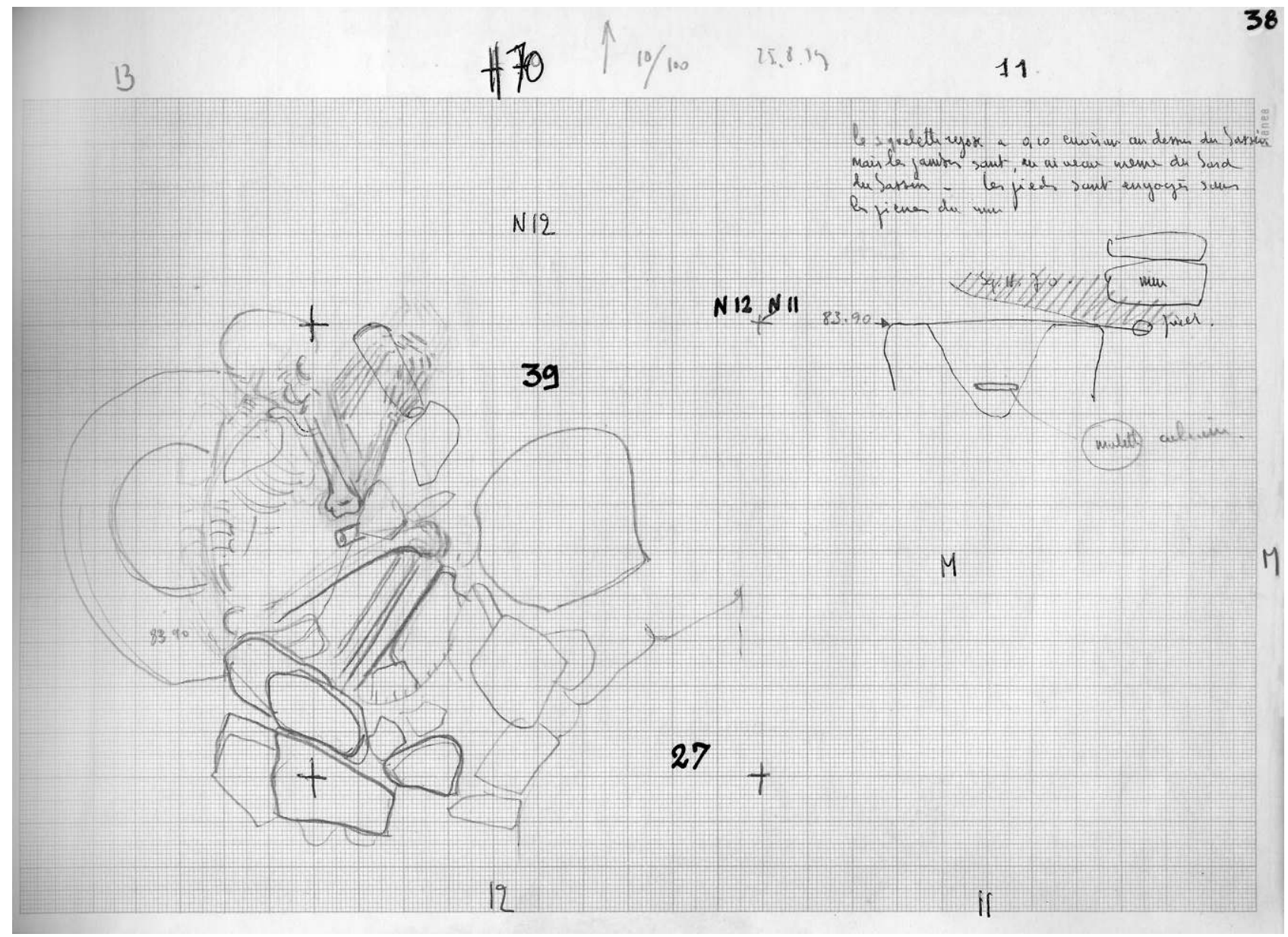

Figure 10. Drawings of grave H70 (Mallaha) and comments: "The skeleton lies about 0.10 [centimetres] above the basin [deep mortar] but the legs are level with the edge of the basin. The feet are engaged under the stones of the wall". J. Perrot 25/8/1959 (C) Archives from the Fonds Perrot, JP554. Maison des Sciences de l'Homme, Nanterre) / Croquis de la tombe H70 (Mallaha) et commentaires "Le squelette se trouve à environ 0,10 [centimètre] au-dessus du bassin [mortier profond] mais les jambes sont au niveau du bord du bassin. Les pieds sont engagés sous les pierres du mur". J. Perrot 25/08/1959 (C) Archives du Fonds Perrot, JP554. Maison des Sciences de l'Homme, Nanterre)

\section{Staging of the dead and their funerals}

The internal organisation of the graves also seems to be closely related to the construction of a relationship between the world of the living and that of the dead. Some graves, especially among the earliest, seem to narrate an individual or collective memory through an elaborate staging of the burials. The deceased, or more frequently the deceased buried together, were not necessarily the centre of attention: their place in the grave is shared, even peripheral (Bocquentin 2014; 2021). There may be an accumulation of corpses in neat but unusual positions, or a group of individuals arranged in a circle around a broken mortar, or a complex arrangement associating the dead with dogs (the only domestic animal) and/or selected remains of hunted species (Valla, 1999; 2012; Grosman et al., 2008). While each staging is unique, they all follow certain rules that are common to all Natufian communities. The position and orientation of the corpse, the objects placed on it or accompanying it, are specific to each site. The dead person at the centre of the event is the messenger of the values and identity of his or her community, whether these values are an extension of those of the world of the living in death or specific to the funerary world. Burial position and orientation do not seem to be linked to age or sex but to places (cave vs. open areas), phases (more and more constrained over time), specific events (forms of staging), sites (absence/ presence of certain positions), and individual identities (no strict standardization). Ornaments condense identities at different levels: their presence or absence depends on the chronological phase; the categories of beads, their quantity and their location on the body are site-specific. In cases of multiple burials, only one individual is ornamented (Belfer-Cohen, 1995), but their position in the grave is neither central nor random. Generally speaking, most beads are worn by young males (Bocquentin, 2003) but there are 


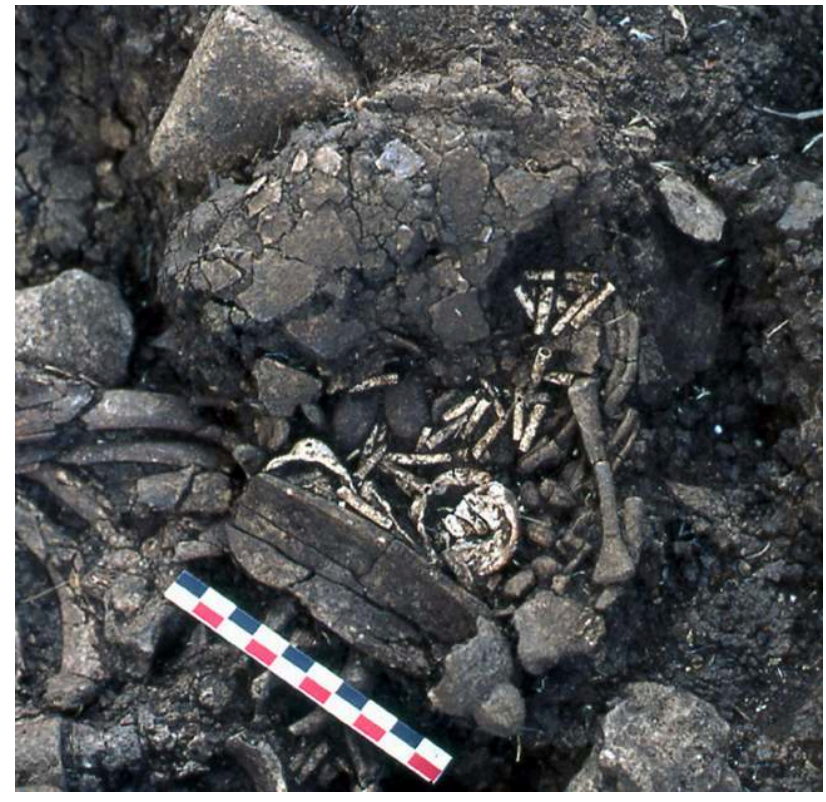

Figure 11. Grave H176 (Mallaha). A perinatal was buried with a richly ornamented necklace and a bone spoon, both extremely rare at the site (C) F. Valla) / Tombe H176 (Mallaha). Un périnatal a été enterré avec un collier fourni et une cuillère en os, tous deux étant extrêmement rares sur le site (C) F. Valla)

notable exceptions, such as the two decorated infants found at Mallaha (Perrot and Ladiray, 1988; Valla et al., 2007, Davin 2019; figure 11). Overall, the exact role of the ornaments cannot be clearly determined but their ritual and collective identity value seems obvious and was probably greater than any kind of individual status. The grave provided a space for expression and sharing in a strict ritual setting, providing a new landmark in a world in turmoil. It is difficult, in this ritual complexity, to identify, among the dead already elected for eternal rest within the hamlet, any who might have had privileged affinities with the living, or more authority than others, although such a hypothesis cannot be ruled out.

\section{Making the dead visible and enduring}

A period clearly emerges when the close geographical relationship between the living and the dead began to loosen, with the appearance of dedicated burial places during the Late Natufian. These burials took place in permanently abandoned structures (Hayonim Cave) at some distance from the living spaces (Nahal Oren, Eynan-Mallaha, El Wad), or in dedicated caves (Raqefet, Hilazon Tachtit). The dead and the living were becoming disentangled. Was it a matter of distancing the dead who had become too cumbersome? Was it to draw a clear boundary between worlds that had become too closely intertwined? Or was there an extrinsic reason that demanded an adaptation of the treatment of the dead to new constraints? The instability of occupation and the return to a certain form of nomadism documented by archaeological data (Byrd, 2005; Henry, 2013; Weissbrod et al., 2017) could have been reasons for adapting burial customs. The establishment of these dedicated areas, which can be considered as the very first cemeteries (in the sense of an area exclusively and permanently dedicated to the dead), was accompanied by two notable phenomena. Firstly, burying the dead in graves away from dwellings made them visible; secondly, they would endure over time. These two aspects could well have been not the consequences but, on the contrary, the driving forces behind the topographical reorganisation observed.

The issue of visibility is indeed salient. Until then, tombs had been relatively discreet, enclosed within built structures and soon buried by the continuity of successive occupations, but now they became visible to all. At Nahal Oren, the graves are marked by deep, wide boulder mortar (Noy, 1989); at Hayonim, the stone containers are increasingly elaborate. At Mallaha, the dedicated burial area has a concentration of large burial pits capped by an upright elongate stone (figure 12). Not only did funerary architecture evolve towards more visible forms, but the phenomenon of aggregating the dead together in these dedicated spaces was totally new and probably spectacular. The graves were visible to all members of the community but probably also to neighbours passing nearby. This would give full meaning to the commonly accepted view that graves mark a territory, which could hardly have been the case when they were hidden within dwellings.

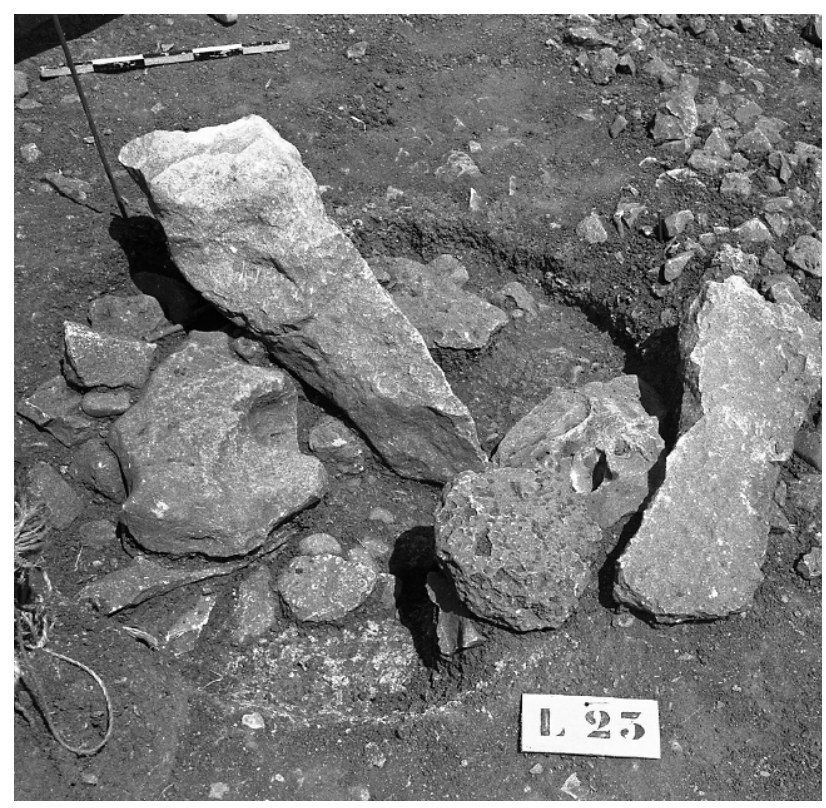

Figure 12. Collective grave at Locus 23 (Mallaha). Note the elongated stone, still partially erect, and the remains of lime plaster on part of the wall and on the base of the burial pit (C) Archives from the Fonds Perrot, JP583, Maison des Sciences de l'Homme, Nanterre) / Sépulture collective Locus 23 (Mallaha). Noter la pierre allongée encore partiellement dressée et les restes d'enduit de chaux sur une partie du mur et sur la base de la fosse funéraire (@) Archives du Fonds Perrot, JP583, Maison des Sciences de l'Homme, Nanterre) 
There was also a major change in the way the funeral time-span was considered, as supported by a change in the treatment of corpses. Now grouped together in specialised, marked and accessible areas, the dead became subject to more complex and prolonged mortuary treatments. It was during this period that the removal of skulls intensified and became part of a multi-stage funerary treatment that was not opportunistic but planned in advance as early as the primary burial (see Bocquentin et al., 2016). In EynanMallaha, where skull removal is not documented during the Natufian period, the change concerns the development of collective graves in which the dead were buried one after the other, sharing the same resting place, which remained empty of sediment over time. It should be noted that although clusters of dead did exist before, these were clusters of mostly individual deposits in juxtaposed individual pits, wrongly considered as "collective graves". It was only from the very end of the Early Natufian that real successive multiple deposits did appear (for instance at Azraq 18: Bocquentin and Garrard, 2016). These successive deposits caused a dislocation of the individual skeletons resulting in a collective commingled body that was manipulated over a long period of time. The receiving structures are large lime plastered pits which may have been previously used as food storage structures (Perrot and Ladiray, 1988) and which subsequently ensured permanent preservation of the remains of the deceased.

\section{Final remarks and interpretative suggestions}

For contemporary sedentary people of long standing, the Natufian burial phenomenon seems unsurprising today. However, although some burials predated the Natufian, notably during the Geometric Kebarian period (e.g. Bocquentin et al., 2011; Maher et al., 2011), the recurrent interment of the dead must be considered as a major transformation in human societies, just as much so as the beginning of funerary treatments in the Middle Palaeolithic. Although the burial of corpses would seem to be a way of hiding the dead and of sparing the living from the decomposition that takes place (e.g. Thomas, 1996; Crubézy, 2019), the choice of burying the dead in this Natufian context reflects purposes that are much less pragmatic than symbolic. This at least is what is suggested by the close proximity, either geographical or gestural, that the living established with their dead. Instead of hiding the dead, their burial seems on the contrary to be a way of keeping the dead close to the living, of grouping, accessing, preserving and transmitting the deceased over the long term. The practice of burial brought a new material reality to the world of death. The selection of the deceased, their meticulously chosen location, their placement in the tomb, their possible integration with existing or future architecture and their individual or collective fate all point to a rigorously planned and codified ritual process, whose purpose does not seem to be limited to the treatment of the corpse but extends to the preparation of a post-mortem role assignment in alliance with the living (Bocquentin, 2022). The dead are strongly invested in the transmission of an identity, a place, and sometimes a narrative.

Over the Natufian period, two distinct funerary patterns stand out: in the case of places shared with the living, we observe that in the majority of cases, the integrity of the body is preserved, buried in a single or multiple/collective grave, in a single bag or pit; the grave is discreet if not hidden, and the handling of the dead is of short duration. In the case of dedicated places for the dead, we observe the exact opposite: ostentation, aggregation and prolonged funerary handling. Could this have been an adaptation of different needs of the living? The dead placed close to the living would play a part in the functional organization of the hamlets and could even have had a role of humanizing, in the literal sense, the permanent living place, through specific contributions: corpses, dry bones and dead spirits could have helped to domesticate a place by giving it a permanent human imprint as opposed to the rest of the world. On the other hand, spatially distancing the dead from the living could have endowed them with a function as guardians of the collective memory and habitat of a group in fear of social disruption. These two possibilities, while not strictly excluding others, seem to be closely linked to the lifestyle and occupation of the territory. It is interesting to note that the possible return to a mobile life was not accompanied by a return to ephemeral funerary practices: on the contrary, the dead were increasingly called upon. Their function had changed: they no longer played a part in structuring the hamlet, which may no longer have existed, but they did play a part in the memorising of places and in building up a stable collective entity. Nothing appears to have been left to chance, and through the treatment of their corpses, the dead served to anchor the village and the world in a specific spatio-symbolic system in which humans, whether living or dead, were becoming more and more central.

\section{Acknowledgments}

I would like to thank François Valla and Hamoudi Khalaily for their help and support in the field at Mallaha, as well as Nicolas Samuelian and Laurent Davin for sharing the plans they produced from the original field drawings. I would also like to thank Elisabeth Bellon and Nathalie Dupuis for providing me with all the necessary documents from the archives of the Fonds Perrot, which are curated at the MSH Mondes in Nanterre. I am grateful to both reviewers for their very supportive words that accompanied their review and for their comments that helped to refine and enrich the initial text. I would also like to warmly thank the co-coordinators of this session for the stimulating exchanges we had on this scientific topic, which I hope will continue in the near future. 


\section{References}

Bar-Yosef O, Goren N (1973) Natufian remains in Hayonim Cave. Paléorient 1:49-68 [https://doi.org/10.3406/paleo.1973.899]

Bar-Yosef O, Valla F (2013) Natufian foragers in the Levant: Terminal Pleistocene social changes in Western Asia, Archaeological series. International Monographs in Prehistory, Ann Arbor

Belfer-Cohen A (1995) Rethinking social stratification in the Natufian culture: The evidence from burials. In: Campbell S, Green A (ed) The Archaeology of Death in the Ancient Near East. The short Run Press, Exeter, pp 9-16

Belfer-Cohen A, Hovers E (1992) In the eye of the beholder: Mousterian and Natufian burials in the Levant. Current Anthropology 33:463-471 [https://doi.org/10.1086/204098]

Bocquentin F (2020) L'Épipaléolithique : une lente marche vers la sédentarisation. In: Sauvage M (ed) Atlas historique du Proche-Orient ancien. Les Belles Lettres/IFPO, Paris, pp 14-17

Belfer-Cohen A, Schepartz LA, Arensburg B et al (1991) New biological data for the Natufian population in Israel. In: The Natufian Culture in the Levant. International Monographs in Prehistory, Ann Arbor, pp 411-424

Bocquentin F (2003) Pratiques funéraires, paramètres biologiques et identités culturelles au Natoufien : une analyse archéoanthropologique. Thèse de doctorat, Université Bordeaux 1

Bocquentin F (2007) A final Natufian population: health and burial status at Eynan-Mallaha. In: Zilberman U, Faerman M, Horwitz LK et al (ed) Faces from the Past: Diachronic Patterns in the Biology of Human Populations from the Eastern Mediterranean. Papers in Honour of Patricia Smith. Archaeopress, Oxford, pp 66-81

Bocquentin F (2014) Frail echoes from Natufian mortar sounds of ritual food processing. Comments on "The sounds of pounding: boulder mortars and their significance to Natufian burial customs" by Danny Rosenberg and Dani Nadel. Current Anthropology 55:799-800

Bocquentin F (2022) Beyond the formal analysis of funerary practices? Archaeothantology as a reflexive tool for considering the role of the dead amongst the living: A Natufian case study. In: Knüsel CJ, Schotsmans EMJ (ed) The Routledge Handbook of Archaeothanatology. Routledge, London.

Bocquentin F, Chambon P, Le Goff I. et al (2010) De la récurrence à la norme : interpréter les pratiques funéraires en préhistoire. Bulletins et Mémoires de la Société d'anthropologie de Paris 22:157-171 [https://doi.org/10.1007/s13219-010-0017-8]

Bocquentin F, Garrard A (2016) Natufian collective burial practice and cranial pigmentation: A reconstruction from Azraq 18 (Jordan). Journal of Archaeological Science: Reports 10:693702 [https://doi.org/10.1016/j.jasrep.2016.05.030]

Bocquentin F, Crevecoeur I, Arensburg B et al (2011) Les hommes du Kébarien géométrique de Neve David, Mont Carmel (Israël). Bulletins et mémoires de la Société d'anthropologie de Paris 23: 38-51 [https://doi.org/10.1007/s13219-010-0032-9]

Bocquentin F, Kodas E, Ortiz A (2016) Headless but still eloquent! Acephalous skeletons as witnesses of Pre-Pottery Neolithic North-South Levant connections and disconnections. Paléorient 42:33-52 [https://doi.org/10.3406/paleo.2016.5719]
Byrd BF (2005) Reassessing the emergence of village life in the Near East. Journal of Archaeological Research 13:231-290

Crubézy E (2019) Aux origines des rites funéraires. Voir, cacher, sacraliser. Odile Jacob, Paris

Davin L (2019) La parure du Natoufien ancien en contexte funéraire : reconstitution des chaînes opératoires à Mallaha (Eynan), Israël. Thèse de doctorat, Université Paris 1

Edwards PC, Anton M, Bocquentin F et al (2018) La Trobe University's 2016 season of field sampling and archaeological excavation at the site of Wadi Hammeh 27. Annual of the Department of Antiquities of Jordan 59:273-290

Edwards PC, Major J, McNamara K et al (2019) The Natural inspiration for Natufian art: Cases from Wadi Hammeh 27, Jordan. Cambridge Archaeological Journal 29:607-624 [https://doi.org/10.1017/S0959774319000234]

Enzel Y, Bar-Yosef O (2017) Quaternary of the Levant: Environments, Climate Change, and Humans, $1^{\text {st }}$ ed. Cambridge University Press [https://doi.org/10.1017/9781316106754]

Gagnol L (2011) Le territoire peut-il être nomade ? Espace et pouvoir au sein des sociétés fluides et mobiles. L'Information Géographique 75:86-97

Garrod DAE, Bates DMA (1937) Mugharet el Wad description and excavations. In: The Stone Age of Mt. Carmel. Clarendon Press, Oxford

Grosman L, Munro ND, Belfer-Cohen A (2008) A 12,000-yearold Shaman burial from the southern Levant (Israel). Proceedings of the National Academy of Sciences USA 105:17665 [https://doi.org/10.1073/pnas.0806030105]

Grosman L, Munro ND, Abadi I et al (2016) Nahal Ein Gev II, a Late Natufian community at the Sea of Galilee. PLOS ONE 11: 21-48 [https://doi.org/10.1371/journal.pone.0146647]

Henry DO (2013) The Natufian and the Younger Dryas. In: Bar-Yosef O, Valla F (ed) Natufian Foragers in the Levant: Terminal Pleistocene Social Changes in Western Asia [Papers from a Symposium Held in 2009]. Archaeological Series, Ann Arbor, pp 584-610

Hoppa RD (2002) Paleodemography: looking back and thinking ahead. In: Hoppa RD, Vaupel JW (ed) Paleodemography. Age Distribution from Skeletal Samples. Cambridge University Press, Cambridge, pp 9-28

Hovers E, Belfer-Cohen A (2013) Insights into early mortuary practices of Homo. In: Tarlow S, Nilsson Stutz L (ed) The Oxford Handbook of the Archaeology of Death and Burial. Oxford University Press, Oxford, pp 631-642

Ledermann S (1969) Nouvelles tables-types de mortalité. INED / PUF (Travaux et Documents, 53), Paris

Maher LA, Stock JT, Finney S et al (2011) A unique human-fox burial from a Pre-Natufian cemetery in the Levant (Jordan). PLoS ONE 6:e15815 [https://doi.org/10.1371/journal.pone. 0015815]

Noy T (1989) Some aspects of Natufian mortuary behavior at Nahal Oren. In: Hershkovitz I (ed) People and Culture in Change: Proceedings of the Second Symposium on Upper Palaeolithic, Mesolithic and Neolithic Populations of Europe and the Mediterranean Basin; Part 1. British Archaeological Reports, International series, Oxford 
Perrot J (1960) Excavations at Eynan (Ain Mallaha): Preliminary report on the 1959 season. Israel Exploration Journal 10:14-22

Perrot J (1966) Le gisement natoufien de Mallaha. L'Anthropologie 70:437-484

Perrot J, Ladiray D (1988) Les Hommes de Mallaha (Eynan), Israel. Association Paléorient (Mémoires et Travaux du Centre de Recherche Française de Jérusalem 7), Paris

Ramsey MN, Maher LA, Macdonald DA et al (2016) Risk, reliability and resilience: Phytolith evidence for alternative 'Neolithization' pathways at Kharaneh IV in the Azraq Basin, Jordan. PLOS ONE 11:e0164081 [https://doi.org/10.1371/journal. pone.0164081]

Richter T, Bocaege E, Ilsøe P et al (2019) Ochre, ground stone, and wrapping the dead in the Late Epipalaeolithic (Natufian) Levant: Revealing the funerary practices at Shubayqa 1, Jordan. Journal of Field Archaeology 44:440-457 [https://doi.org/ 10.1080/00934690.2019.1645546]

Santana J, Millard A, Ibáñez-Estevez JJ et al (2021) Multi-isotope evidence of population aggregation in the Natufian and scant migration during the early Neolithic of the Southern Levant. Scientific Reports 11:11857 [https://doi.org/10.1038/s41598021-90795-2]

Samuelian N (2019) Les abris du Natoufien final de Eynan-Mallaha, Israël. Organisation spatiale et interprétation fonctionnelle. Éditions de Boccard (Mémoires et Travaux du Centre de Recherche Français de Jérusalem 11), Paris

Sellier P (1996) La mise en évidence d'anomalies démographiques et leur interprétation: population, recrutement et pratiques funéraires du tumulus de Courtesoult. In: Piningre JF (ed) Nécropoles et société au premier âge du Fer : le tumulus de Courtesoult (Haute-Saône). Éditions de la Maison des Sciences de l'Homme (DAF, 54), Paris, pp 188-200

Smith P (1973) Family burials at Hayonim. Paléorient 1 :69-71 [https://doi.org/10.3406/paleo.1973.900]

Terradas X, Ibáñez J, Braemer F et al (2013) The Natufian occupations of Qarassa 3 (Sweida, Southern Syria). In: International Monographs in Prehistory, Archaeological Series, pp 45-60 [https://doi.org/10.2307/j.ctv8bt33h.9]

Thomas L-V (1996). Rites de Mort. Fayard éditions, Paris

Valla F (1988) Aspects du sol de l'abri 131 de Mallaha (Eynan), Israël. In: Préhistoire du Levant II. Processus des changements culturels, Paléorient 14:283-296 [https://doi.org/10.3406/ paleo.1988.4475]

Valla F (1999) The Natufian: a coherent thought? In: Davies W, Charles R (ed) Dorroty Garrod and the Progress of the Paleolithic: Studies in the Prehistoric Archaeology of the Near East and Europe. Oxbow Books, Oxford, pp 224-241
Valla F (2012) Les fouilles de la terrasse d'Hayonim (Israël), 1980-1981 et 1985-1989. Éditions de Boccard (Mémoires et travaux du centre de recherche français à Jérusalem 10), Paris

Valla F (2018) Sedentism, the "point of non return", and the Natufian issue. An historical perspective. Paléorient 44:19-33

Valla F (2019) More on Early Natufian building 131 at Eynan (Ain Mallaha), Israel. In: Goldfus H, Gruber MI, Yonah S et al (ed) "Isaac Went out to the Field": Studies in Archaeology and Ancient Cultures in Honor of Isaac Gilead. Archaeopress Archaeology, Oxford, pp 302-315

Valla F, Bocquentin F (2008) Les maisons, les vivants, les morts : le cas de Mallaha (Eynan), Israël. In: Balkan N, Molist M, Stordeur D (ed) Houses for the Living and a Place for the Dead. Proceedings of the $5^{\text {th }}$ International Congress on the Archaeology of the Ancient Near East, Universidad Autónoma De Madrid, Madrid, pp 521-542

Valla F, Khalaily H, Samuelian N et al (2001) Le Natoufien final de Mallaha (Eynan), deuxième rapport préliminaire : les fouilles de 1998 et 1999. Journal of the Israel Prehistoric Society 31: 83-184

Valla F, Khalaily H, Valladas H et al (2004) Les fouilles de Mallaha en 2000 et $2001: 3^{\text {ème }}$ rapport préliminaire. Journal of the Israel Prehistoric Society 34:49-244

Valla F, Khalaily H, Valladas H et al (2007) Les fouilles de Aïn Mallaha (Eynan) de 2003 à 2005 : quatrième rapport préliminaire. Journal of the Israel Prehistoric Society 37:135-383

Vandermeersch B, Bar-Yosef O (2019) The Paleolithic burials at Qafzeh Cave, Israel. PALEO. Revue d'Archéologie Préhistorique 30:256-275 [https://doi.org/10.4000/paleo.4848]

Webb SG, Edwards PC (2002) The Natufian human skeletal remains from Wadi Hammeh 27 (Jordan). Paléorient 28:103124 [https://doi.org/10.3406/paleo.2002.4741]

Weissbrod L, Marshall FB, Valla F et al (2017) Origins of house mice in ecological niches created by settled hunter-gatherers in the Levant 15,000 y ago. Proceedings of the National Academy of Sciences USA 114:4099-4104 [https://doi.org/10.1073/ pnas.1619137114]

Yeshurun R, Bar-Oz G (2018) Ungulate skeletal element profiles: A possible marker for territorial contraction and sedentism in the Levantine Epipaleolithic. "Humans and Quaternary Environments in the Levant" in Honour of Professor Mina Weinstein-Evron, Quaternary International 464:173-186 [https:// doi.org/10.1016/j.quaint.2017.04.036] 